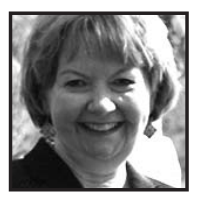

\title{
Regaining the Love of Learning
}

\author{
Cecilia Reynolds, University of Saskatchewan
}

\begin{abstract}
This article points to two trends of critical importance for pre-K-12 and postsecondary institutions - the growth of technologies for learning and the need to enhance Indigenous education. With the help of technologies, we must move away from old aspirations of "covering" the curriculum, toward inquiry approaches that help us regain the love of learning. With guidance from the exciting Accord on Indigenous Education drafted by the Association of Canadian Deans of Education, we must transform relations between Aboriginal and non-Aboriginal people across Canada and all educational settings must become beacons of hope for Aboriginal communities.
\end{abstract}

f you were to ask me, "What are the two most important areas of work within Canadian education right now?"-I would respond that they are the use of technologies in learning and future directions for Indigenous education.

I have been proud to call myself a teacher all of my adult life. At the age of sixteen, having completed just one year of teacher education following high school, I found myself in front of a boisterous group of fourteen year-olds in what was then called the "Jane-Finch corridor" in Toronto. It was a notorious area, full of immigrants, rebellious youth and paved over schoolyards. My students and I muddled through that year and in the end we learned how to respect each other and value our time together. In retrospect, it was a perfect start to my long career as an educator. That career has taken me into elementary and secondary classrooms throughout Ontario and into professor, researcher and administrator's roles in three different Canadian universities. 
At present, I continue to work as a scholar and researcher interested in gender relations, equity and social justice. While my work is now often in places outside Canada and my "teaching" is often with groups of policymakers, the challenges I faced in my first year and the lessons I learned remain.

As Dean of Education at the University of Saskatchewan, my role entails ensuring support for the ongoing research of our faculty and students in and across the various disciplines related to "education." My role also includes oversight of a relatively large set of graduate programs and a large teacher education program that contains some historically successful routes for the preparation of Aboriginal teachers. Although there are many challenges ahead for Canadian education, my recent experiences have convinced me that technologies for learning and "Indigenous Education" are areas of great promise for the future of Canadian education.

Today, the digital age is upon us. Technologies both enhance and confuse our daily lives. Each of us manages multiple forms of communication, from cell phones to e-mail and beyond. In our educational sites, whether these be K-12 school systems, postsecondary institutions, early childhood environments or lifelong learning settings, teaching and learning activities can harness technological tools but stuffing "content" into our heads is no more desirable than it ever was. We still gain more by learning how to fish than by being handed a string of fish.

All of us are enriched by innovative approaches to teaching and learning that improve the process of learning rather than trying to "cover" a curriculum. And, while mathematics and science skills are important, reading for the joy of it, artistic expression and appreciation that feeds our spirits and hard to measure dispositions such as improved empathy must in my view, be considered as part of all our teaching and learning encounters. As I remember it, in my first classroom much of the valuable long-term learning was caught rather than taught.

Increasingly, technologies help us reach out to find learners "where they live" rather than insisting that they need to travel to us in traditional classroom settings where face-to-face instruction is the only means of learning available. As we move forward in education, I believe the joy of learning must remain front and centre. The measures of our learning must be able to tell us how to enhance further learning. I am a strong advocate of assessment for learning and fear that some government approaches of assessment of learning are very much off-base and ultimately harmful. When we start where learners are and travel with them in ways that use technological tools and the latest information we have about the brain and how it works, 
we are moving in ways that improve education. One whole set of strategies that is critical is the set clustered around learning within Aboriginal communities and learning between people in non-Aboriginal and Aboriginal communities. As we say in Saskatchewan:"We are all Treaty People."

Throughout our country, just as in my first classroom in the Jane-Finch corridor, we are still trying to learn how to respect each other. Learning how to value our Aboriginal peoples and their Indigenous knowledge and approaches to life remains critical for all of us. Recently, the Association of Canadian Deans of Education (ACDE) ratified an Accord on Indigenous Education that is available on the Association's Web site. It is an ambitious blueprint of how to proceed. In my view, it is one of the most important documents I have ever helped to create.

Following a preamble, the Accord maps out a brief history of the shifting contexts for Indigenous education in our country for First Nations, Métis and Inuit peoples. In summary, this has included a complex maze of jurisdictional issues involving the federal government, the provinces and Aboriginal communities in many regional settings. The Accord stipulates that today, while there are more than 500 First Nations schools on Indian reserves and 51 Aboriginal postsecondary institutions, the majority of Aboriginal and non-Aboriginal students attend schools where "there is often no or limited influence on Indigenous curricular or organizational matters" (Association of Canadian Deans of Education, 2009, p. 4).

The vision of the ACDE Accord is that "Indigenous identities, cultures, values, ways of knowing and knowledge systems will flourish in all Canadian learning settings" (p. 4). The Accord maps out the following overarching categories for specific goals which we all should strive to reach: respectful and welcoming learning environments; respectful and inclusive curricula; culturally responsive pedagogies; mechanisms for valuing and promoting Indigeneity in education; culturally responsive assessment; affirming and revitalizing Indigenous languages; Indigenous educational leadership; non-Indigenous learners and Indigeneity; and culturally respectful Indigenous research (pp. 5-8).

We cannot redo history. We can, however, decide to move forward acknowledging the need to rethink past assumptions and see the promise and potential in all our children and youth, not just those from certain types of backgrounds or in specific circumstances. My class in the Jane-Finch corridor was enriched, not impoverished by the "differences" among those in our group. For years, I have been pointing out that equality, often equated with sameness, should not be the goal in our education 
systems or our society. Rather, it is equity, the treatment of people according to their differences that marks a truly just system within our communities and organizations. People often ask me what makes a good teacher. I believe that there is no simple answer to this question. Teachers are as diverse as the learners we work with. We are as gifted and flawed as anyone. We have our strengths and challenges. Like other teachers, I am continuing to become a teacher, despite having been on that quest for many years. Like my peers, I continue to want to make a difference in local and global settings. If education is a journey, it is one we all travel. My personal stance has been to strive to be an informed traveler and to resist the temptation to be a consuming tourist. As I learned in my first year as a teacher, this is not easy, but who ever said that something worthwhile would ever be easy!

\section{References}

Association of Canadian Deans of Education (2009). Accord on Indigenous education. Retrieved April 12, 2010, from http:// www.csse.ca/ACDE/IndigenousEducation Accord.pdf 


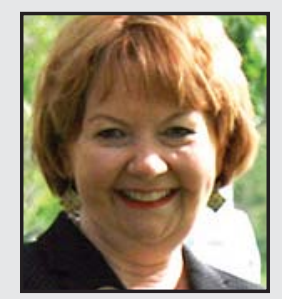

Cecilia Reynolds is in her second term as Professor and Dean of the College of Education of the University of Saskatchewan in Saskatoon. Following seventeen years as a teacher in elementary and secondary classrooms, she completed her PhD at the Ontario Institute for the Study of Education at the University of Toronto. As a faculty member at Brock University from 1986-1998, she was the Director of Women's Studies and then Chair of the Graduate Department of the Faculty of Education. Dr. Reynolds was elected to the first Governing Council of the Ontario College of Teachers and served as the Chair of the Accreditation Committee. At OISE/UT from 1999-2003, she served as the Associate Dean, Academic. Her research has focused on gender and equity issues in education. She has published four edited books on leadership as well as a number of chapters and journal articles related to her research.

\section{LINK TO:}

www.usask.ca/education/

www.educ.sfu.ca/aboriginal_education/documents/ACDE_Accord_Indigenous_ Education_000.pdf 